\title{
COMPARISON OF TWO SIMPLIFICATION METHODS FOR SHORELINE EXTRACTION FROM DIGITAL ORTHOPHOTO IMAGES
}

\author{
B. Bayram ${ }^{1, *}$, A. Sen ${ }^{1}$, M.O. Selbesoglu ${ }^{1}$, I. Vārna ${ }^{2}$, P. Petersons ${ }^{3}$, N.O. Aykut ${ }^{1}$, D. Z. Seker ${ }^{4}$ \\ ${ }^{1}$ Yildiz Technical University, Civil Engineering Faculty, Dept. of Geomatic Engineering, Davutpasa Campus, 34220 Esenler- \\ Istanbul, Turkey - (bayram, alpersen, oguzs, oaykut)@ yildiz.edu.tr \\ ${ }^{2}$ University of Latvia, Institute of Geodesy and Geoinformation, 19 Raina Blvd. LV 1586, Riga, Latvia- inesej@inbox.lv \\ ${ }^{3}$ Latvian Geospatial Information Agency Ojāra Vaciesa 43, Riga, Latvia, LV-1004- peteris.petersons@ @igia.gov.lv \\ ${ }^{4}$ ITU, Civil Engineering Faculty, 80626 Maslak Istanbul, Turkey - seker@itu.edu.tr
}

KEY WORDS: SLIC, shoreline extraction, shoreline simplification, Image segmentation, orthophoto image

\begin{abstract}
:
The coastal ecosystems are very sensitive to external influences. Coastal resources such as sand dunes, coral reefs and mangroves has vital importance to prevent coastal erosion. Human based effects also threats the coastal areas. Therefore, the change of coastal areas should be monitored. Up-to-date, accurate shoreline information is indispensable for coastal managers and decision makers. Remote sensing and image processing techniques give a big opportunity to obtain reliable shoreline information. In the presented study, NIR bands of seven 1:5000 scaled digital orthophoto images of Riga Bay-Latvia have been used. The Object-oriented Simple Linear Clustering method has been utilized to extract shoreline of Riga Bay. Bend and Douglas-Peucker methods have been used to simplify the extracted shoreline to test the effect of both methods. Photogrammetrically digitized shoreline has been taken as reference data to compare obtained results. The accuracy assessment has been realised by Digital Shoreline Analysis tool. As a result, the achieved shoreline by the Bend method has been found closer to the extracted shoreline with Simple Linear Clustering method.
\end{abstract}

\section{INTRODUCTION}

Global warming and its effects are one of the main topics for scientists (Deng et al., 2014). According to International Union of Geological Sciences (IUGS), shorelines are one of the vital and vulnerable environmental heritages ( $\mathrm{Li}$, et al., 2001). Coastal areas are very complex ecosystems and socio-economic environment (Raju et al., 2015). They contain large variety of habitats which are important for survival of biodiversity and (Gammal, et al., 2016). The biological and physical characteristics of coastal areas can change because of physical reasons and anthropogenic processes (Pareeth, et al., 2017). Therefore monitoring of shoreline is essential to protect environmental heritage areas (Addo, 2013). Up-to-date and reliable shoreline information is indispensable for coastal managers (Jawak, et al., 2015).

Remote sensing and geographical information system (GIS) provides new technologic advantages in costal monitoring studies (Maiti and Bhattacharya, 2009). Monitoring of shoreline is fundamental for planning, defining of hazard zones, and predicting of erosion and sediment transport (Bayram et al., 2013).

Image processing techniques can provide reliable solutions for shoreline extraction issue. Several pixel and object-oriented methods have been proposed. Iterative Self Organized Data Analysis (ISODATA) (Guariglia, et al., 2006), thresholding and morphological filtering (Pardo-Pascual, et al., 2012, Bayram et al., 2008), non-separable wavelet transform (Yu, et al., 2013 ), active contour models (Shmitt, et al., 2015), genetic algorithm based methods (Yousef and Iftekharuddin, 2014), particle swarm optimization method (PSO) (Bayram, et al., 2016), Random forest method (Erdem et al., 2017), mean-shift segmentation (Wu, et al., 2009), object-oriented fuzzy classification approaches (Bayram et al., 2017; Bayram et al., 2015), Support Vector Machine (Kalkan, et al. 2013) can be counted as mainly used methods for shoreline extraction.

In the presented study Simple Linear Clustering segmentation method has been employed and shoreline Gulf of Riga (GoR) has been extracted. Douglas-Peucker and Bend simplification algorithms have been implemented for simplification of extracted shoreline and their effect on accuracy assessment has been tested. The photogrammetrically digitized shoreline of GoR has been taken as reference data for evaluation of the results.

\section{STUDY AREA}

The Latvian shoreline is about $500 \mathrm{~km}$. The $85 \%$ sandy beach coastline is under threat of erosion, deposition, increasing of inhabitants and urbanisation, summer houses (Ebehards, et al.,2006). GoR is rich of coastal resources and natural biodiversity. Bullusala Island located in the south part of the GoR, between entry of river Daugava in the East, entry of river Lielupe in the West and river Bullupe in the South. Island has been formed in the 18th century during the floods of Lielupe. Also at present peripheral rivers influence the coastline changes of Bullusala and its surroundings. This study is focused on the 16 $\mathrm{km}$ part of GoR which is selected as the study area (Figure 1).

\section{MATERIAL AND METHOD}

In this study NIR band of the 1:5000 scaled seven digital orthophoto images of Bullusala and Bullupe in Riga-Latvia in the year of 2013 were used. Presented study consists of main three parts which are (i) shoreline extraction using Simple Linear Clustering (SLIC) method, (ii) simplification of extracted shoreline by Douglas-Peucker and Bend algorithms, (iii)

\footnotetext{
* Corresponding author
} 
searching effects of both simplification methods with Digital Shoreline Analysis System (DSAS).

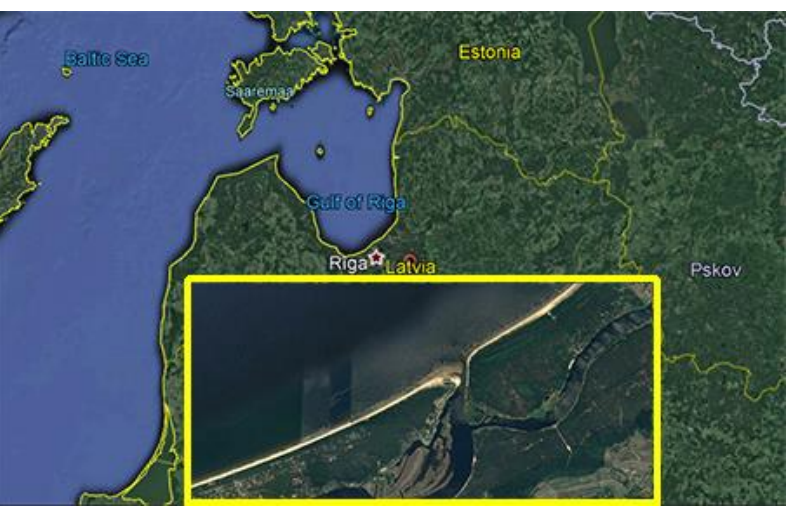

Figure 1. The study area.

\subsection{Implementation of SLIC}

In the first step of the study, shoreline extraction has been accomplished. For this purpose, Superpixels have been created to obtain homogeneous segments. SLIC algorithm is an efficient object-oriented segmentation method which is based on spatially localized version of K-means clustering method. The detailed information about SLIC can be found in Achanta, et al. (2012).

K-means is based on the standard Lloyd algorithm (Lloyd, 1982). Compare to K-means algorithm, by SLIC, each pixel is assigned only to the centre of neighbour tiles. Once superpixels are created, the area of superpixel is checked according to user defined minimum region size (Vedaldi and Fulkerson, 2010). MATLAB environment has been used for utilizing SLIC algorithm. For all seven orthophoto images the same paremeters have been used. The number of the superpixels and compactness were chosen 15000 and 0.5 respectively. The created superpixels are given in Figure 2.

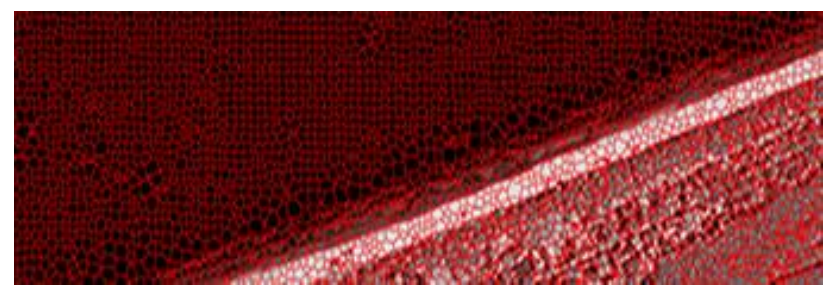

Figure 2. Created superpixels.

In the next step, thresholding has been implemented to create Land and Water-body classes from segmented image. The thresholding parameters are given in Table 1. Following to thresholding, editing has been employed. Editing module has been created to edit wrongly classified segments after thresholding. The aim of the editing is to add or to delete segments from image which are belonging to wrong class by using selected superpixels. A sample of the editing process is given in Figure 3. Noise removal step has been implemented to eliminate noisy pixels by using region analysis tool of MATLAB after editing. The final binary image is given in Figure 4 .

\begin{tabular}{|c|l|}
\hline Image No & Thershold value \\
\hline 1 & $124-255$ \\
\hline 2 & $110-255$ \\
\hline 3 & $50-255$ \\
\hline 4 & $113-255$ \\
\hline 5 & $150-255$ \\
\hline 6 & $30-255$ \\
\hline 7 & $90-255$ \\
\hline
\end{tabular}

Table 1. Thresholding parameters.

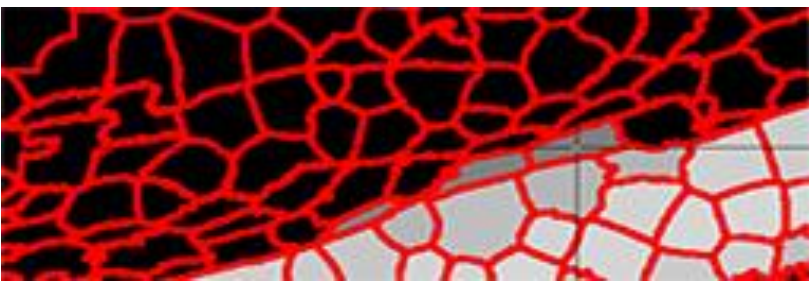

Figure 3. Editing process.

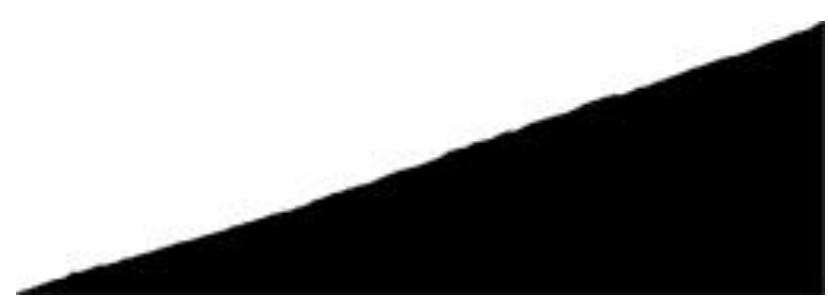

Figure 4. Resulted binary image.

The shoreline of GoR has been obtained by applying raster to vector transformation after creation of all seven binary images from orthophoto maps.

\subsection{Simplification of extracted shoreline}

Generalization is needed in order to represent relevant information on an appropriate level of detail (Ai et al., 2014). Simplification approach reduces the number of points of the feature, with the restriction that the characteristic shape of the feature is preserved Simplification approach eliminates insignificant vertices of the feature with the restriction of preserving the essential shape (Sester, 2000).

There are two main restrictions in the shoreline generalization. One of them is preserving the pattern of coastline, which is related with geomorphologic properties. The other one is keeping important characteristics such as estuary sources. (Ai et al., 2014).

Wang and Muller (1998) proposed an algorithm for generalization based on bend simplification. The algorithm preserves the overall structure with line bends by detecting their size, shape and context mathematically and eliminating insignificant ones. The algorithm preserves the overall structure with line bends, which are mathematically defined related to size, shape and context. According to (Wang and Muller, 1998), a bend is defined by the algorithm as a part of a line in which a number of subsequent vertices are contained. A Bend contains inflection angles of all vertices with positive or negative sign. Opposite signs set the two end vertices of a bend's inflection. The bend elimination depends on the comparison of the tolerance value and the geometric measures of the bend. Other commonly proposed simplification method is Douglas-Peucker algorithm 
(1973) which takes into account the maximal perpendicular distance of points from a hypothetical generalized trend line. Perpendicular distance measurement is taken as unique criteria for point selection by the algorithm. If the distance between trend lines and vertices are smaller than the tolerance value than these vertices are eliminated (Sester, 2000).

The tolerance values of Douglas-Peucker and Bend simplification methods are determined by considering of cartographic legibility and aesthetic aspects (Burghardt and Schmid, 2009). In the presented study, tolerance values have been taken as according to limit of visual perception as approximately $0.2 \mathrm{~mm}$ at a reading of $30 \mathrm{~cm}$ (Burghardt and Schmid, 2009) which corresponds to the ground sample distance of digital orthophoto images.

Both simplification methods have been utilized to simplify extracted shoreline and compared with the photogrammetrically digitized shoreline of GoR. The total length and the number of vertices of the row data and simplified shorelines are given in Table 2. As it can be seen in Table 2, Douglas-Peucker simplification results of extracted shoreline get closer to the photogrammetric digitizing. However, the Douglas-Peucker algorithm produced some sharp bends which were illegible at the target scale (1:5000) and caused self-intersection issues as shown in the brown box in Figure 5. The Bend algorithm produced the simplified features which were smoother than the DouglasPeucker, and closer to the line extracted by SLIC algorithm.

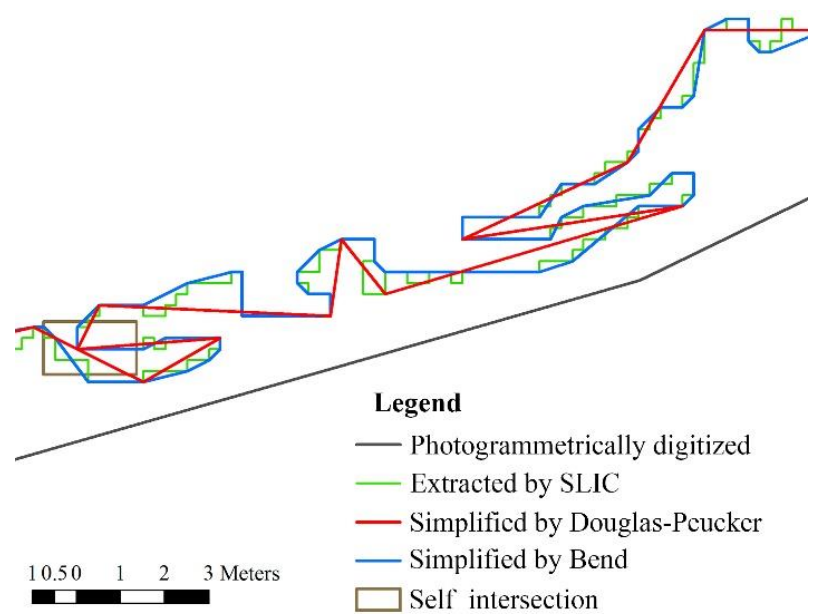

Figure 5. Results of Douglas-Peucker and Bend methods.

Extracted shoreline by SLIC and photogrammetric evaluation results are given in Figure 6.

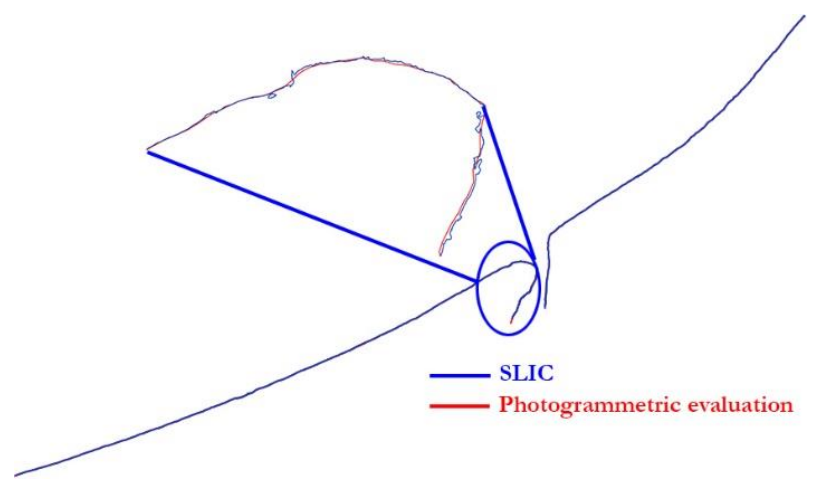

Figure 6. Shoreline extraction by SLIC

\begin{tabular}{|c|c|c|}
\hline Methods & $\begin{array}{c}\text { Length } \\
(\mathbf{k m})\end{array}$ & $\begin{array}{c}\text { Number of } \\
\text { Vertices }\end{array}$ \\
\hline $\begin{array}{c}\text { Photogrammetric } \\
\text { evaluation }\end{array}$ & 15.86 & 907 \\
\hline Extracted by SLIC & 23,35 & 59404 \\
\hline $\begin{array}{c}\text { Douglas-Peucker to } \\
\text { SLIC line }\end{array}$ & 17,19 & 1798 \\
\hline Bend to SLIC line & 18,56 & 18438 \\
\hline
\end{tabular}

Table 2. Total length and the number of vertices of shoreline.

In the last step of the study, the extracted and simplified shorelines have been compared with created shoreline by photogrammetric process of GoR. This step has been realized by Digital Shoreline Analysis System (DSAS) (Thieler et al., 2009). DSAS is a tool for evaluation a shoreline with reference data (Jayson-Quashigah et al., 2013). The Net Shoreline Movement function of DSAS has been employed for comparison which calculates perpendicular distances with defined spacing between input and reference data (Oyedotun, 2014).

The spacing, transect length and buffer size has been chosen as $10 \mathrm{~m}, 75 \mathrm{~m}$ and $30 \mathrm{~m}$ respectively.

A sample for evaluation of Bend method with photogrammetrically digitized shoreline is given in Figure 7. The accuracy assessment results are given in Table 3 .

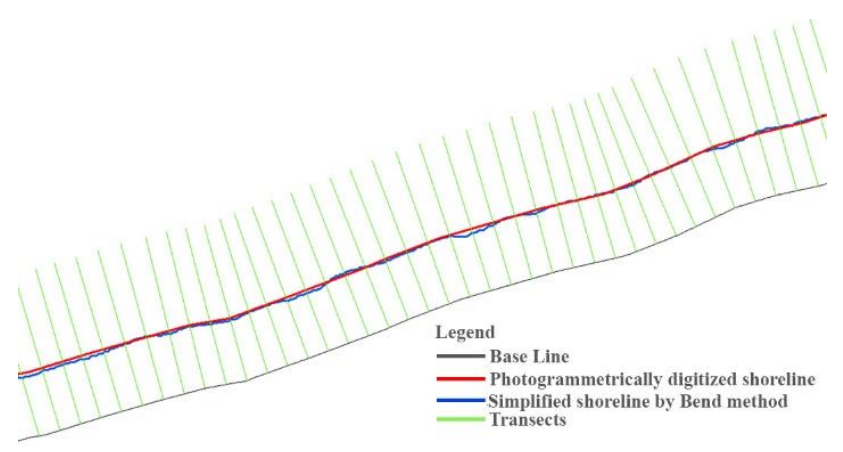

Figure 7. Evaluation of shoreline simplification with reference data.

\section{RESULTS AND CONCLUSIONS}

According to Table 3, the results of Bend method are closer to original extracted shorelines. While calculated ratios in $0.0-1.0 \mathrm{~m}$ distance for SLIC and Bend method are $50.65 \%$ and $50.98 \%$ respectively, the ratio for Douglas-Peucker method is $49.71 \%$. Similar to this, the ratios for $1.0-2.5,2.5-5.0,5.0-7.5$ and $>7.5 \mathrm{~m}$ distance of Bend method are close to calculated distances for SLIC. The statistical analysis results are given in Table 4. 


\begin{tabular}{|c|c|c|c|c|c|c|}
\hline \multirow{2}{*}{ Method } & $\begin{array}{c}\text { Calculated } \\
\text { distance } \\
(\mathrm{m})\end{array}$ & $\begin{array}{c}0.0- \\
1.0\end{array}$ & $\begin{array}{c}1.0- \\
2.5\end{array}$ & $\begin{array}{c}2.5- \\
5.0\end{array}$ & $\begin{array}{c}5.0- \\
7.5\end{array}$ & $>7.5$ \\
\hline \multirow{2}{*}{ SLIC } & $\begin{array}{c}\text { Number of } \\
\text { transects }\end{array}$ & 776 & 496 & 181 & 50 & 29 \\
\cline { 2 - 7 } & Ratio (\%) & 50.65 & 32.38 & 11.81 & 3.26 & 1.89 \\
\hline \multirow{2}{*}{ Bend } & $\begin{array}{c}\text { Number of } \\
\text { transects }\end{array}$ & 781 & 489 & 182 & 52 & 28 \\
\cline { 2 - 7 } & Ratio (\%) & 50.98 & 31.92 & 11.88 & 3.39 & 1.83 \\
\hline \multirow{2}{*}{$\begin{array}{c}\text { Douglas- } \\
\text { Peucker }\end{array}$} & $\begin{array}{c}\text { Number of } \\
\text { transects }\end{array}$ & 762 & 509 & 185 & 46 & 31 \\
\cline { 2 - 8 } & Ratio (\%) & 49.71 & 33.20 & 12.07 & 3.00 & 2.02 \\
\hline
\end{tabular}

Table 3. Accuracy assessment results.

\begin{tabular}{c|ccc} 
Statistics $(\mathrm{m})$ & BEND & DOUGLAS & SLIC \\
\hline Minimum & -13.81 & -13.82 & -12.58 \\
Maximum & 13.54 & 13.80 & 10.91 \\
Mean & 0.28 & 0.30 & 0.46 \\
$\begin{array}{c}\text { Standard } \\
\text { deviation }\end{array}$ & 2.40 & 2.38 & 3.66 \\
RMS & 2.41 & 2.40 & 3.69
\end{tabular}

Table 4. Statistics of the methods.

As a result of the statistical analyses, standard deviations have been found $2.4 \mathrm{~m}, 2.38 \mathrm{~m}$ and $3.69 \mathrm{~m}$ for Bend method, DouglasPeucker method and unsimplified shoreline respectively. The \% 95 of distance difference values have been found in $\pm 4.69 \mathrm{~m}$ for Bend method, $\pm 4.66 \mathrm{~m}$ for Douglas-Peucker method and \pm 7.18 $\mathrm{m}$ for unsimplified method according to confidence interval $(\alpha=0.05)$. The statistics show that the results of Bend and Douglas-Peucker methods are close to each other and provides more precise results than the unsimplified shoreline data. From this point of view it can be said that simplification process can be used for shoreline extraction.

In the future studies, more complex shoreline data will be simplified using Bend and Douglas-Peucker methods to test their effects to the accuracy assessment.

\section{REFERENCES}

Achanta, R., Shaji, A., Smith, K., Lucchi, A., Fua, P., \& Süsstrunk, S., 2012. SLIC Superpixels Compared to State-of-theArt Superpixel Methods, IEEE Transactions on Pattern Analysis and Machine Intelligence, 34(11), 2274-2282. https://doi.org/10.1109/TPAMI.2012.120.

Addo, K.A., 2013. Shoreline morphological changes and the human factor. Case study of Accra Ghana. Journal of Coastal Conservation. 17 (1), 85-91.

Ai, T., Zhou,Q., Zhang, X., Huang Y. and Zhou M. 2014. A Simplification of Ria Coastline with Geomorphologic Characteristics Preserved. Marine Geodesy, Volume 37, 2014 Issue 2: Special Issue on Coastal and Marine Geographic Information Systems, p 167-186, http://dx.doi.org/10.1080/01490419.2014.903215.

Bayram B., Avşar E. Ö., Şeker D. Z., Kayi A., Erdoğan M., Eker O., Janpaule I., Çatal R. H.., 2017. The Role Of National And
International Geospatial Data Sources In Coastal Zone Management. Fresenius Environmental Bulletin, 26(1), pp. 383391.

Bayram B., Demir N., Ogurlu M., Catal R. H., Seker D. Z., 2016. 3D Shoreline Extraction Using Orthopoto-Maps and LIDAR. In: 37 th Asian Conference on Remote Sensing, 17-21 October 2016, Sri Lanka, Colombo, pp.1-5.

Bayram B., Janpaula I., Avsar O., Ogurlu M., Bozkurt S., Catal Reis H., Seker, D.Z., 2015. Shoreline Extraction and Change Detection using 1:5000 Scale Orthophoto Maps: A Case Study of Latvia-Riga, International Journal of Environment and Geoinformatics, 2(3), pp. 1-6.

Bayram B., Seker D. Z., Acar U., Yuksel Y., Guner A. H. A., Cetin, I., 2013. An Integrated Approach to Temporal Monitoring of the Shoreline and Basin of Terkos Lake. Journal of Coastal Research, 29(6), pp. 1427-1435.

Bayram B., Acar U., Seker D. Z., Ari A., 2008. A Novel Algorithm for Coast Line Fitting Through A Case Study Over Bosphorus. Journal of Coastal Research, 24(4), pp. 983-991.

Burghardt D, Schmid S., 2010. Constraint-based evaluation of automated and manual generalised topographic maps. In: Gartner G, Ortag $F$ (eds) Cartography in central and eastern Europe. Lecture Notes in Geoinformation and Cartography, Springer, pp 147-162.

Douglas, D.H.; Peucker T.K., 1973. Algorithms for the reduction of the number of points required to represent a digitized line or its caricature. Can. Cartogr, 10, 112-122.

Eberhards, G., Lapinskis, J., Saltupe, B., 2006. Hurricane Erwin 2005 coastal erosion in Latvia. Baltica 19 (1), 10-19.

Erdem F., Nasırzadehdızajı R., Derinpınar M.A., D.Z. Seker, Bayram.B., 2017. Shoreline extraction using Random Forest Case study: Istanbul/Terkos, In: Proceeding of IXth TUFUAB Technical Symposium, 27-29 April, Afyon-Turkey, pp. 84-89.

Deng, H.J., Chen, Y.N., Shi, X., Li, W.H., Wang, H.J., Zhang, S.H., Fang, G.H., 2014. Dynamics of temperature and precipitation extremes and their spatial variation in the arid region of northwest China. Atmospheric Research, 138, 346-355.

Gammal J., Norkko, J., Pilditch, C. A., Norkko A., 2016. Coastal Hypoxia and the Importance of Benthic Macrofauna Communities for Ecosystem Functioning. Estuaries and Coasts, DOI 10.1007/s12237-016-0152-7.

Guariglia, A., Buonamassa, A., Losurdo, A., Saladino, R., Trivigno, M. L., Zaccagnino, A., 2006. A multisource approach for coastline mapping \& identification of the shoreline changes, Annals of Geophysics, 49(1), 295-304.

Jayson-Quashigah, P. N., Addo, K. A., Kodzo, K. S., 2013. Medium resolution satellite imagery as a tool for monitoring shoreline change. Case study of the Eastern coast of Ghana, Journal of Coastal Research, 65(sp1), pp. 511-516.

Jawak S. D., Kulkarni K., Luis A. J., 2015. A Review on Extraction of Lakes from Remotely Sensed Optical Satellite Data with a Special Focus on Cryospheric Lakes. Advances in Remote Sensing, 4, 196-213. 
Kalkan, K.,Bayram, B., Maktav, D., Sunar, F. 2013. Comparison of support vector machine and object based classification methods for coastline detection, ISPRS Conference on "Serving Society with Geoinformatics, 11-17 Nov. 2013, Antalya-Turkey, ISPRS - International Archives of the Photogrammetry, Remote Sensing and Spatial Information Sciences, Volume XL-7/W2, 2013, p.125-127.

Li, R., K. Di., R. Ma., 2001. A Comparative Study of Shoreline Mapping Techniques. In: 4th International Symposium on Computer Mapping and GIS for Coastal Zone Management ,1820 June 2001, Halifax, Nova Scotia, Canada.

Lloyd, S., 1982. Least squares quantization in PCM. IEEE Transactions on Information Theory, 28(2), 129-137. https://doi.org/10.1109/TIT.1982.1056489.

Maiti, S., Bhattacharya, A.K., 2009. Shoreline change analysis and its application to prediction: a remote sensing and statistics based approach, Marine Geology, 257, 11-23.

Oyedotun, T. D. T., 2014. Shoreline Geometry: DSAS as a Tool for Historical Trend Analysis. Geomorphological Techniques, Chap. 3, Sec. 2.2 (2014), 12.

Pardo-Pascual J. E., Almonacid-Caballer J., Ruiz L. A., PalomarVázquez J., 2012. Automatic extraction of shorelines from Landsat TM and ETM+ multi-temporal images with subpixel precision, Remote Sensing of Environment, $123,1-11$.

Pareeth S., Bresciani M., Buzzi F., Leoni B., Lepori F., Ludovisi A., Morabito G., Adrian R., Neteler M., Salmaso N. 2017, Warming trends of perialpine lakes from homogenised time series of historical satellite and in-situ data, Science of the Total Environment 578 , 417-426.

Raju, A., Dwarakish, G.S., Venkat, R. 2015. Automatic Shoreline Detection and Change Detection Analysis of NetravatiGurpur Rivermouth Using Histogram Equalization and Adaptive Thresholding Techniques, Aquatic Procedia, 4, 563 - 570.

Schmitt, M., Lingyun, W., Xiao X. Z., 2015. Automatic Coastline Detection in Non-locally Filtered TANDEM-X Data. In: Proceedings of IEEE International Geoscience and Remote Sensing Symposium (IGARSS) 2015, IEEE Xplore. IGARSS 2015, 26.-31. Jul. 2015, Mailand, Italien. pp. 1036-1039.

Sester, M. 2000. Generalization Based On Least Squares Adjustment. In: International Archives of Photogrammetry and Remote Sensing, Vol. XXXIII, Part B4. Amsterdam, p.931-938.

Thieler, E. R., Himmelstoss, E. A., Zichichi, J. L., Ergul, A., 2009. Digital Shoreline Analysis System (DSAS) version 4.0 An ArcGIS extension for calculating shoreline change. U.S. Geological Survey Open-File Report. pp. 2008-1278.

Vedaldi, A., Fulkerson, B., 2010. Vlfeat. In: Proceedings of the international conference on Multimedia - MM '10 (p. 1469). New York, New York, USA: ACM Press. https://doi.org10.1145/1873951.1874249.

Wang, Z.; Muller, J.C., 1998. Line generalization based on analysis of shape characteristics. Cartography and Geographic Information Science, 25, 3-15, DOI: $10.1559 / 152304098782441750$.
Wu H., Liu C., Zhang Y., Sun W., 2009. Water feature extraction from aerial-image fused with airborne LIDAR data. In: IEEE Urban Remote Sensing Event, 2009 Joint, pp. 1-7.

Yousef A., Iftekharuddin K., 2014. Shoreline extraction from the fusion of LiDAR DEM data and aerial images using mutual information and genetic algorithms. In: 2014 International Joint Conference on Neural Networks (IJCNN). Beijing, China, pp. $1007-1014$

Yu S., Mou Y., Xu d., You X., Zhou L., Zeng W., 2013. A New Algorithm for Shoreline Extraction from Satellite Imagery with Non-Separable Wavelet and Level Set Method. International Journal of Machine Learning and Computing, 3(1), pp. 158-163. 